\title{
Water Uptake by Older Roots: Evidence From Desert Succulents
}

\author{
Gretchen B. North and Evan A. Baker \\ Department of Biology, Occidental College, 1600 Campus Road, Los Angeles, CA 90041 \\ Additional index words. root hydraulic conductance, contractile roots, Agavaceae, Agave deserti, Yucca schidigera
}

\begin{abstract}
Desert succulents are renowned for their rapid recovery of shoot function after periods of drought as a result of shoot succulence, root-shoot interactions, and key root properties. Near the base of the shoot, the proximal (generally older) roots appear to play a major role in the rapid uptake and delivery of water, especially after a period of soil drying when the rest of the root system has a lower hydraulic conductance. In all of the cacti, agaves, and yuccas examined to date, hydraulic conductance for the proximal root zone is unexpectedly high. Substantial water uptake by older roots of cacti is associated with much higher axial (xylem) hydraulic conductance in proximal than in distal root regions. For agaves and yuccas, proximal roots have other anatomical and physiological traits that enhance water uptake near the shoot base. Despite suberization (waxiness) of external root tissues in the proximal region, internal cell layers appear more characteristic of young root regions with living cortical cells and a high proportion of unsuberized passage cells in the endodermis. Both features may be related to the existence of a contractile root zone possessed by all members of the Agavaceae surveyed to date. Passage cells in the endodermis and aquaporins (protein water channels) in the metabolically active cortex expedite radial water transport. The radial swelling that accompanies longitudinal root contraction may also help maintain rootto-soil contact that would otherwise be diminished in dry soil. Modifications that increase axial and radial hydraulic conductance in the proximal root region suggest that water uptake by older roots is critical to the success of desert succulents.
\end{abstract}

For desert succulents, and for several other plant species, older roots play a more active role in water uptake than is generally acknowledged. We suggest that older roots of most plants can and do take up water, and we discuss in more detail the evidence from desert succulents showing the important contribution of older roots, particularly with respect to recovery after drought. In the case of the succulents discussed here, the term "older roots" refers to the proximal root region near the base of the shoot, $\approx 10$ to 15 $\mathrm{cm}$ long, in which roots are mature with suberized (waxy) outermost cell layers but are of relatively small diameter $(8 \mathrm{~mm}$ or less). With respect to chronological age, this region has been investigated in roots ranging from 5 months to 2 years old. The species considered here occur in arid to semiarid habitats in which rainfall is infrequent and often fails to wet more than the uppermost $10 \mathrm{~cm}$ of soil. Thus, the location of older roots near the soil surface makes their ability to absorb water critically important in dry lands. Their shallow distribution also has implications for the physiology and management of other plants that lack deep roots. For example, preliminary evidence suggests that older, shallower roots of 2-year-old chaparral shrubs are capable of greater water uptake than are younger, deeper roots (G.B. North, unpublished observations).

In most biology textbooks, root water uptake is described as occurring primarily near the apical meristem, in the region where

\footnotetext{
We thank Jim Syvertsen for the invitation to present a version of this paper as part of the 2006 ASHS Colloquium entitled "Mechanisms of RootShoot Communication," Maren Roe and Stephanie Sakamoto for assistance with data collection, and the National Science Foundation for financial support (grant \# 0517740 to GBN)
}

root hairs first appear (Taiz and Zeiger, 2002). Further back from the tip, internal and external suberized cell layers (the endodermis and exodermis, respectively, and later the periderm) are said to make the root relatively impermeable to water (Purves et al., 2004). A few texts, however, do acknowledge the potential involvement of older roots (Zimmermann and Brown, 1971), and a number of studies conducted in the last 25 years demonstrate that water is taken up along the length of the root. One of the most elegant of these is by MacFall et al. (1991), who showed with magnetic resonance imaging that the woody tap root of a loblolly pine seedling extracts more water from the surrounding sand than does a young lateral root in the same zone. In other studies with both woody and herbaceous species, water uptake occurs well back from the root tip, particularly in regions of lateral root emergence (Clarkson et al., 1987; Häussling et al., 1988; Sanderson, 1983). Indirect evidence for the involvement of older roots in supplying water comes from the recovery of stomatal opening and sap flow too quickly after the cessation of drought to be attributed to growth of new roots (Dubrovsky and North, 2002; Green and Clothier, 1999).

One explanation for the ability of older root regions to remain absorptive is that soil moisture is heterogeneous, and that even in dry soil, there remain microsites such as under rocks where water is more available than in the bulk soil. Not only may such sites allow more prolonged water uptake, but they may also delay the root suberization process that is normally hastened by soil drying (Cruz et al., 1992; North and Nobel, 1991). In a divided pot experiment, with two dry soil compartments flanking a middle compartment with wet soil, roots of the monocotyledonous leaf succulent Agave deserti that developed in wet soil remain less suberized than roots that developed in drying soil, even when the root region in wet soil is older than the region in dry soil. In addition, hydraulic conductance (a root's capacity to absorb and transport water) is higher for segments of older roots from the wet soil compartment than it is for younger segments from dry soil (North and Nobel, 2000). An unexpected result of this experiment is that root segments from the dry soil compartment nearest the shoot base, the oldest roots, have the highest hydraulic conductance.

The anatomy of the proximal root region also appears in some respects to be developmentally immature; in particular, the endodermis has a larger proportion of unsuberized (and therefore presumably more absorptive) passage cells than are present in younger, more distal root regions. The other endodermal cells in the proximal region have thinner, less suberized cell walls. One explanation is that the oldest root region of $A$. deserti can remain less suberized than expected because of its proximity to the succulent shoot, which maintains relatively high plant water potential even during drought (North and Nobel, 2000). In an earlier investigation, a fluorescent tracer fed to a leaf base indicated that roots of $A$. deserti do indeed import water from the shoot when the water potential of the soil is lower than that of the shoot (North and Nobel, 1998). The internal supply of water may help explain the relatively unsuberized state of the endodermis in contrast to the extensive suberization and lignification of the more external cell layers in the proximal region of the root, including the outer cortex and exodermis.

More recent work with roots of $A$. deserti has shown that the relatively high hydraulic conductance of the proximal root region is associated not only with reduced endodermal suberization, but also with aquaporins (protein water channels in cell membranes), 
which contribute substantially to water uptake in the distal and proximal root regions but not at midroot, where cortical cells tend to collapse or become lignified before dying (North et al., 2004). The expression and physical state of aquaporins has been linked with metabolic processes such as phosphorylation (Johansson et al., 1998). Thus, it makes sense that the root regions of $A$. deserti with the greatest evidence of aquaporin activity are those with living cortical cells, i.e., the distal and proximal regions (North et al., 2004).

When plants of $A$. deserti are grown in moist soil, the differences in hydraulic conductance along roots are even clearer and are exhibited by other succulent species as well (Fig. 1). Both A. deserti and Yucca brevifolia (Joshua tree) are monocotyledons in the family Agavaceae, whereas Ferocactus cylindraceus is a eudicotyledon in the Cactaceae. Such differences in phylogeny are associated with differences in root anatomy that in turn are associated with different explanations for the greater hydraulic conductance of proximal (older) roots. Because $F$. cylindraceus is a eudicot, the vascular tissues in its roots undergo secondary growth, leading to increases in vessel number and diameter with root age. For example, the number of vessels in roots of $F$. cylindraceus is 10 times greater for 12-month-old roots than for 1-month-old roots and the vessel diameter is more than twice as great. As a consequence, axial conductance (through the xylem) is $\approx 50$ times greater for the older roots (North and Nobel, 1992). Although axial conductance does not usually limit root water uptake (Frensch and Steudle, 1989; North and Peterson, 2005), the development of secondary xylem explains the pattern of hydraulic conductance shown for $F$. cylindraceus in Figure 1.

Because both $A$. deserti and $Y$. brevifolia are monocots, xylem vessels change little in number or diameter along a root once the late metaxylem has matured. Although the axial conductance of distal (young) root segments of $A$. deserti is lower than that of midroot and proximal segments, as a result of the immaturity of the metaxylem in the distal region, the root hydraulic conductance is actually lowest for the midroot region, where axial conductance is highest (North and Nobel, 1998). Root hydraulic conductance reflects the contribution of both the axial (xylem) pathway and the radial pathway (from the root surface to the xylem), so the lower axial conductance of the proximal root region for $A$. deserti is more evidence that the unexpectedly low resistance in the radial pathway must account for the greater hydraulic conductance of the proximal root region (Fig. 1).

The importance of the proximal root region in the recovery of succulents after drought was investigated for greenhousegrown plants of Yucca schidigera (Mojave yucca; Fig. 2). In this experiment, the soil was removed from a $4-\mathrm{cm}$-long region of the proximal roots just below the base of the

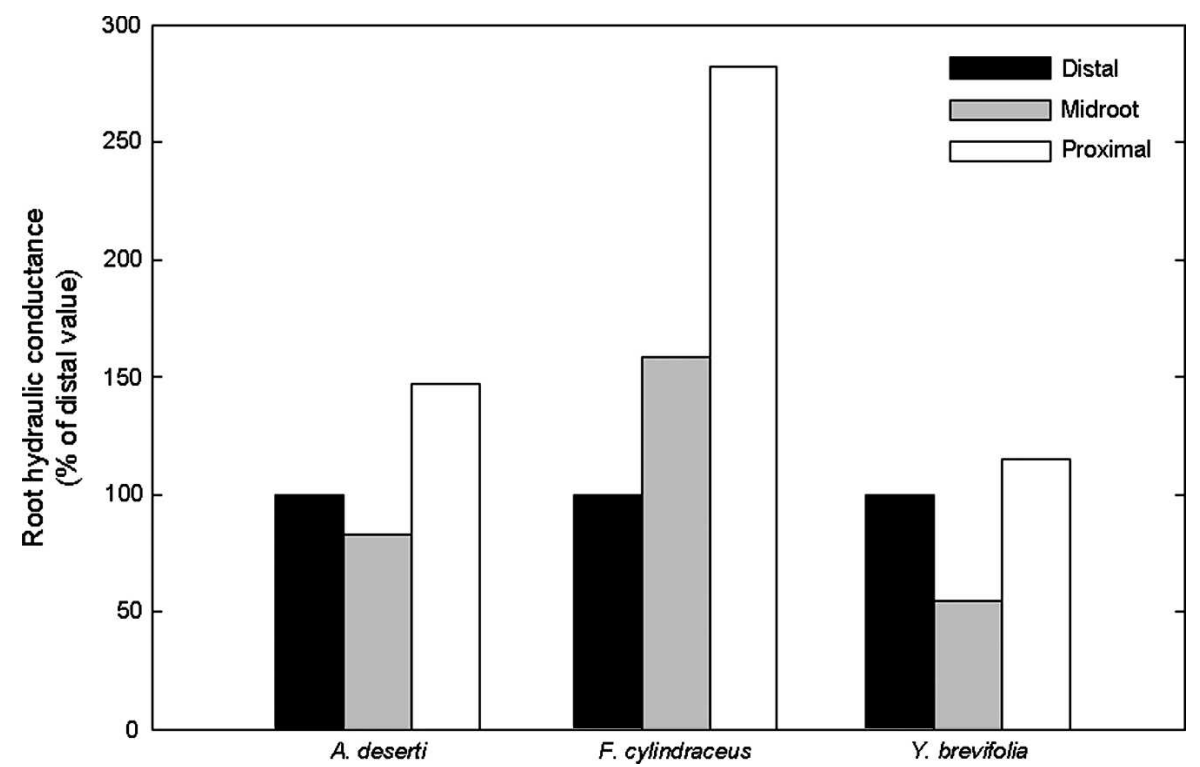

Fig. 1. Root hydraulic conductance for 7-cm-long excised root segments from the distal root region (including the root tip; black bars), at midroot (gray bars), and in the proximal region (near the base of the shoot; open bars) for Agave deserti, Ferocactus cylindraceus, and Yucca brevifolia $(\mathrm{n}=4$ to 6 plants) grown in the greenhouse. Data are expressed as a percentage of the distal value and are taken in part from North and Nobel $(1991,1992)$.

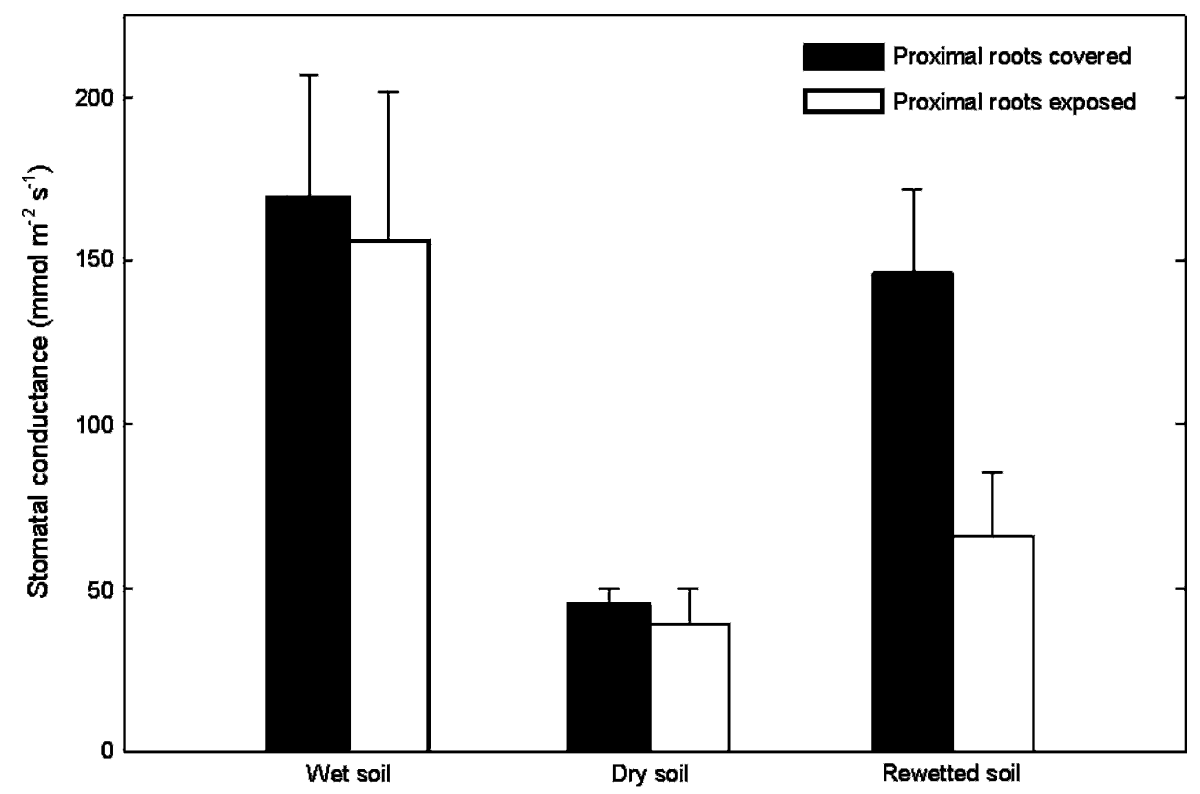

Fig. 2. Stomatal conductance $\left(g_{\mathrm{S}}\right)$ [measured with a LI-COR (Lincoln, NE) 1600 porometer] of greenhouse-grown 2-year-old plants of Yucca schidigera after $14 \mathrm{~d}$ in wet soil followed by $14 \mathrm{~d}$ of soil drying and $2 \mathrm{~d}$ of rewetting measured on plants with all roots covered by potting soil (black bars) and on plants with proximal roots exposed by removing soil from a 4-cm-long region of the roots at the base of the shoots (open bars). Data are means $\pm \mathrm{SE} ; \mathrm{n}=8$ plants for each treatment.

shoot (exposed roots) for one set of plants. Stomatal conductance $\left(g_{\mathrm{S}}\right)$ was measured for these plants along with a set of control plants (covered roots) after $14 \mathrm{~d}$ in wet soil followed by $14 \mathrm{~d}$ of soil drying and $2 \mathrm{~d}$ of rewetting. The goal of uncovering the proximal roots was to prevent them from participating in radial water uptake. For plants in wet and drying soil, $g_{\mathrm{S}}$ was unaffected by exposing the proximal roots. In contrast, $g_{\mathrm{S}}$ after rewetting increased to $86 \%$ of its predrying value for covered control plants but not for plants with proximal roots exposed (Fig. 2). Thus, it appears that this root region contributes disproportionately to the recovery of plant water uptake after the cessation of soil drying as indicated by reduced $g_{\mathrm{S}}$ when proximal roots were not involved. It should be noted that little new root growth was observed when root systems were excavated at the end of the rewetting period. Despite the ability of proximal roots to take up water almost immediately after rewetting, studies with other succulents, including agaves and 

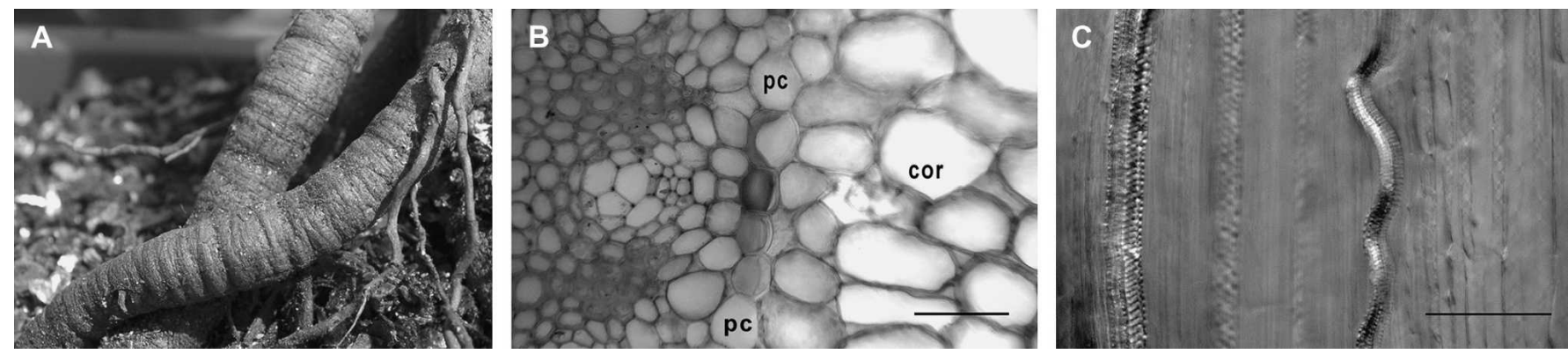

Fig. 3. Photograph and micrographs of the contractile root region, showing (A) the wrinkled exterior of proximal roots of Yucca shidigera, (B) a cross-section taken $5 \mathrm{~cm}$ from the shoot base of a root of $Y$. schidigera after $14 \mathrm{~d}$ in drying soil stained with toluidine blue $\mathrm{O}(\mathrm{pc}=$ passage cells in the endodermis; cor $=$ cortical cells that are elongated in the radial direction), and (C) longitudinal section through the xylem of a root of Hesperoyucca whipplei taken $5 \mathrm{~cm}$ from the shoot base and photographed by Maren Roe. Scale bars $=50 \mu \mathrm{m}$.

cacti, suggested that new root growth is necessary for complete recovery of shoot function after drought (Dubrovsky and North, 2002).

The demonstrated ability of the proximal root region to take up water rapidly is the result of anatomical and physiological features that may in turn be associated with another trait observed in all agaves and yuccas examined to date: the presence of a contractile zone (G.B. North, unpublished data). External evidence for root contraction is radial swelling and transverse wrinkling of the outer cell layers resulting from longitudinal compression as seen at the base of shoots of Mojave yucca (Fig. 3A). In the contractile zone, cells in the inner layers of the root cortex elongate in the radial direction (Fig. 3B) and correspondingly shorten in the longitudinal direction, causing an overall decrease in root length in this region. Other anatomical evidence of root contraction is the sinuous appearance of vessels that are compressed as the root axis shortens (Fig. 3C). The process of root contraction has been described for a number of species, including several bulb-forming members of the Liliaceae and small herbaceous dicots such as dandelion, oxalis, and white clover (Pütz, 2002). Transmission electron microscopy and immunofluorescent labeling have shown that root contraction is accompanied by the reorientation of cellulose microfibrils and microtubules in the radially elongated cells of the root cortex (Smith-Huerta and Jernstedt, 1989).

In most cases, the primary function of contractile roots is to pull the shoot deeper into the soil to escape or better endure unfavorable conditions, including drought, cold temperatures, fire, or grazing (Pütz, 2002). Although specific environmental stresses have not been identified, young plants of several species of agave and yucca are indeed pulled down into the soil by contractile roots. The shoot meristem of Agave mckelveyana, for example, descended an average of $5 \mathrm{~cm}$ below the soil surface during a period of 3 months (G.B. North, unpublished data). For the proximal roots of Mojave yucca, and for those of other yuccas and agaves, cellular features important to radial hydraulic conductance may be functionally associated with root contraction. Specifically, the low level of suberization in the endodermis and adjacent cells of the proximal roots, in contrast to the extensive suberization and thickened cell walls in the endodermis at midroot, may allow the proximal region to contract with less internal deformation than would occur otherwise. In proximal roots, frequent unsuberized passage cells with compressible primary walls in the endodermis may be particularly helpful in this regard (Fig. 3B).

Two other traits of the older, proximal root region besides reduced endodermal suberization may be structurally and functionally associated with both root contraction and improved water uptake. As discussed previously, the relatively high radial hydraulic conductance of the proximal root region is attributable in part to aquaporins, which may be regulated by processes such as phosphorylation that occur only in metabolically active cells (Johansson et al., 1998; North et al., 2004). The cells of the cortex in the contractile root region remain alive longer than those at midroot, even in drying soil (North and Nobel, 1998). Finally, the radial expansion that precedes root contraction may increase and help maintain root contact with the soil, thereby improving the radial path for water uptake.

Because most desert succulents are not deeply rooted (Rundel and Nobel, 1991), the soil column explored by their root systems can be dry for relatively long periods. Older, proximal root regions are located near the soil surface, which may be wetted more frequently than soil at greater depths as a result of light, intermittent rainfall. The position of older roots near the soil surface, as well as near the base of the shoot, enables them to intercept and transport water more quickly to the shoot than can more distal roots. The high axial hydraulic conductance for the proximal root region in cacti and the high radial conductance for the proximal root region in agaves and yuccas assist older roots in their critical role of supplying water to the succulent shoots. For nonsucculent perennials or woody plants during the first few years of growth, older roots may also play a critical role, particularly in arid habitats where soils are more frequently wetted near the surface than at the limited depths explored by the younger roots.

\section{Literature Cited}

Clarkson, D.T., A.W. Robards, J.E. Stephens, and M. Stark. 1987. Suberin lamellae in the hypodermis of maize (Zea mays) roots; development and factors affecting the permeability of hypodermal layers. Plant Cell Environ. 10:83-93.

Cruz, R.T., W.R. Jordan, and M.C. Drew. 1992 Structural changes and associated reduction of hydraulic conductance in roots of Sorghum bicolor $\mathrm{L}$. following exposure to water deficit. Plant Physiol. 99:203-212.

Dubrovsky, J.G. and G.B. North. 2002. Root structure and function, p. 41-56. In: Nobel, P.S. (ed.) Cacti: Biology and uses. University of California Press, Berkeley, CA.

Frensch, J. and E. Steudle. 1989. Axial and radial hydraulic resistance to roots of maize (Zea mays L.). Plant Physiol. 91:719-726.

Green, S. and B. Clothier. 1999. The root zone dynamics of water uptake by a mature apple tree. Plant Soil 206:61-77.

Häussling, M., C.A. Jorns, G. Lehmbecker, C. Hecht-Buchholz, and H. Marschner. 1988. Ion and water uptake in relation to root development in Norway spruce [Picea abies (L.) Karst.]. J. Plant Physiol. 133:486-491.

Johansson, I., M. Karlsson, V.K. Shukla, M.J. Chrispeels, C. Larsson, and P. Kjellbom. 1998. Water transport activity of the plasma membrane aquaporin PM28A is regulated by phosphorylation. Plant Cell 10:451-459.

MacFall, J.S., G.A. Johnson, and P.J. Kramer 1991. Comparative water uptake by roots of different ages in seedlings of loblolly pine (Pinus taeda L.). New Phytol. 119:551-560.

North, G.B., P. Martre, and P.S. Nobel. 2004. Aquaporins account for variations in hydraulic conductance for metabolically active root regions of Agave deserti in wet, dry, and rewetted soil. Plant Cell Environ. 27:219228.

North, G.B. and P.S. Nobel. 1991. Changes in hydraulic conductivity and anatomy caused by drying and rewetting roots of Agave deserti (Agavaceae). Amer. J. Bot. 78:906-915.

North, G.B. and P.S. Nobel. 1992. Droughtinduced changes in hydraulic conductivity and structure in roots of Ferocactus acanthodes and Opuntia ficus-indica. New Phytol. 120:919.

North, G.B. and P.S. Nobel. 1998. Water uptake and structural plasticity along roots of a desert succulent during prolonged drought. Plant Cell Environ. 21:705-713.

North, G.B. and P.S. Nobel. 2000. Heterogeneity in water availability alters cellular development and hydraulic conductivity along roots of 
a desert succulent. Ann. Bot. (Lond.) 85:247255.

North, G.B. and C.A. Peterson. 2005. Water flow in roots: Structural and regulatory features, p. 131-156. In: Holbrook, N.M., and M.A. Zwieniecki (eds.). Vascular transport in plants. Elsevier Academic Press, Burlington, MA.

Purves, W.K., D. Sadava, G.H. Orians, and H.C. Heller. 2004. Life, the science of biology. 7th ed. Sinauer Associates, Inc. and W.H. Freeman and Co., Sunderland, MA.
Pütz, N. 2002. Contractile roots, p. 975-987. In: Waisel, Y., A. Eshel, and U. Kafkafi (eds.). Plant roots: The hidden half 3 rd ed. Marcel Dekker, Inc., New York.

Rundel, P.W. and P.S. Nobel. 1991. Structure and function in desert root systems, p. 349-378. In: Atkinson, D. (ed.). Plant root growth: An ecological perspective. Blackwell Scientific, Oxford.

Sanderson, J. 1983. Water uptake by different regions of the barley root. Pathways of radial flow in relation to development of the endodermis. J. Expt. Bot. 34:240-253.

Smith-Huerta, N.L. and J.A. Jernstedt. 1989. Root contraction in hyacinth III. Orientation of cortical microtubules visualized by immunofluorescence microscopy. Protoplasma 151: $1-10$.

Taiz, L. and E. Zeiger. 2002. Plant physiology. 3rd ed. Sinauer Associates, Inc., Sunderland, MA.

Zimmermann, M.H. and C.L. Brown. 1971. Trees. Structure and function. Springer, Berlin. 